\title{
Preconcentration and Determination of Mercury (II) and Methylmercury in Waters by Immobilized 1,5-Diphenylcarbazone and Cold Vapor Atomic Absorption Spectrometry
}

\author{
Shayessteh Dadfarnia," Ali Mohammed Salmanzadeh, and Ali Mohammed Haji Shabani \\ Depament of Chemistrv, Iazd Cniversitv. Iazd. Iran \\ Received Julv 25, 2002
}

\begin{abstract}
1.5-diphenylcarbazone was immobilized on sodium dodecyl sulfate coated alumina. The alumina particle was effectively used for collection of mercury (II) and methylmerçury cations at sub-ppb level. The adsorbed mercury was eluted with $1 \mathrm{~mol} \mathrm{~L}{ }^{-1}$ of hydrobromic acid solution. The mercury (II) was then directly measured by cold vapor atomic absorption spectrometry utilizing tin (II) chloride where as the total mercury was determined after the oxidation of methylmercury into the inorganic mercury. The methylmercury concentration was calculated by the difference between th e value of total mercury and mercury (II). Mercury (II) and methylmercury cations were completely recovered from water with a preconcentration factor of 100 (for $\mathrm{l} \mathrm{L}$ solution). Relative standard deviation at $\mathrm{Hg} \mathrm{L} \mu \mathrm{g} \mathrm{L}-1$ level $1.7 \%(n=8)$ and the linut of detection was $0.11 \mu \mathrm{g}$ $\mathrm{L}^{-1}$. The procedure was applied to spring water. well water and seawater and accuracy was assessed through recovery experiments.
\end{abstract}

Key Words : Mercury̦ Methỵlmercury, 1.5-Diphenylcarbazone. Cold vapor atomic absorption spectrometry

\section{Introduction}

In recent years. there has been an increased concern over the concentration of mercury in drinking and natural water due to its high toxicity and pollution to the environment. and especially the aquatic system. ${ }^{1.2}$ Mercury is leached from rocks and soil into water system by natural processes. some of which are accelerated by human activities. The World Health Organization (WHO) recommends a limit of $1 \mu \mathrm{g} \mathrm{L}^{-1}$ of mercury in drinking water. ${ }^{2}$ which require a very accurate. selective and sensitive method of measurement. Because of its sumplicity, high sensitivity and relative freedom from interference. cold vapor atonic absorption spectrometry (CVAAS) has generally been used for the determination of mercury. But on account of extremely low concentration of mercury (ng $\mathrm{L}^{-1}$ ) in water samples. the high salinity of seawater, and the growing awareness of environmental mercury pollution. a separation and preconcentration step is required. The most frequent used method for preconcentration of mercury from natural waters is coprecipitation. ${ }^{3}$ solvent extraction. ${ }^{+}$electrochenical precipitation ${ }^{5,6}$ and solid phase extraction. ${ }^{7.9}$ Solid phase extractions with inumobilized organic compounds is attracting great interest because of its high enrichment capability and operation simplicity. Immobilization of organic ligands on the surface of an inorganic or organic solid support is usually aimed to modify the surface with certain target functional groups that can be exploited for further analytical uses.

Chelating sorbents can be obtained in a very simple manner by intpregnation of inorganic or organic solid support with organic ligands. Several method for preconcentration of

\footnotetext{
*Author to whom correspondence should be sent. E-mail: dadfamia2000 athotmail.con
}

mercury utilizing such an approach have been devised; among them are, dithizone inmobilized on different base, ${ }^{1 j-16}$ sulfonic acid dithizone on anion exchanger. ${ }^{17}$ dithiocarbamate resin, ${ }^{18}$ thiomichelers keton, ${ }^{19} \mathrm{~N}$-(2-pyridyl methyl) clitison (PMC) ${ }^{3 j}$ 2,3-dimercapto propane-1-sulfonate (DMPS), ${ }^{21}$ dithiocarbomate, ${ }^{2}$ sodium dietlyyl dithiocarbomate. $^{23}$ dithizone derivative. ${ }^{-4}$ To date no such study has been directed at inmobilization of 1.5-diphenylcarbazone (DPC). a well known classical chelating ligand for mercury extraction. ${ }^{-5}$ So it was considered appropriate to investigate whether this material would adsorb on surfactant coated support in a manner already demonstrated for some ligands. ${ }^{2}$ Studies confinmed the immobilization of 1.5 diphenylcarbazone on surfactant-coated alumina and a rapid and accurate method for preconcentration, and separation of traces of mercury in surface and seawater samples based on CVAAS have been developed.

\section{Experimental Section}

Apparatus. A Buck scientific atonic absorption spectrometer Model 210 VGP was used for all measurement. A mercury hollow cathode lamp was used as the light source, and its operating current was adjusted to the value recommended by the manufacturer. The wavelength used was $253.7 \mathrm{~nm}$ and the bandwidth $0.7 \mathrm{~nm}$.

A Buck scientific hydride vapor generator. Model 1015 was used for mercury generation. The inorganic mercury was reduced to metallic mercury with tin (II) chloride and the mercury generator was operated with nitrogen as carrier gas. The organic mercury was oxidize to inorganic mercury before to analysis by potassium pemanganate, sulfuric acid and nitric acid solution as recommended by Buck scientific 
instruction. $27-29$

The flow of the sample through the column was adjusted with a Leybold vacuum pump model PJ7721-035.3.

Reagents. All the reagents were of analytical-grade. and triply distilled: de-ionized water was used throughout.

A stock $1000 \mu \mathrm{g} \mathrm{mL} \mathrm{m}^{-1}$ of mercury (II) was prepared by dissolving $0.1354 \mathrm{~g}$ of $\mathrm{HgCl}_{2}$ (Merck) in $5 \mathrm{~mL}$ of concentrate nitric acid and was diluted to $100 \mathrm{~mL}$.

A stock methỵlmercury solution $\left(1000 \mu \mathrm{g} \mathrm{mL} \mathrm{L}^{-\mathrm{H}} \mathrm{Hg}\right.$ ) was prepared by dissolving $0.1252 \mathrm{~g}$ of $\mathrm{CH}_{3} \mathrm{HgCl}$ (Merck) in a small amount of acetone in a $100 \mathrm{~mL}$ volumetric flask and was diluted to the mark with water.

A $10 \%(\mathrm{~m} / \mathrm{V})$ tin chloride solution was prepared by dissolving $10 \mathrm{~g} \mathrm{SnCl}_{2}$ in $20 \mathrm{~mL}$ concentrate hydrochloric acid and diluting to $100 \mathrm{~mL}$ with water. A $0.2 \%$ solution of 1.5-diphenylcarbazone (Merck) was prepared by dissolving $0.2 \mathrm{~g}$ of it in $100 \mathrm{~mL}$ ethanol.

Sodium dodecyle sulfate (SDS) (Merck), and 1.5-diphenylcarbazone were used without further purification.

Alumina (10. 50 um. $\alpha, \gamma$ type chromatographic grade. Merck) was purified by shaking with $5 \mathrm{~mol} \mathrm{~L}{ }^{-1}$ nitric acid and washing three times with water. alumina fiber was activated by heating at $500^{\circ} \mathrm{C}$ for 3 hrs as recommended by S.Dadfarnia. 3 Sulfhydryl cotton was prepared according to Lee and Mowter procedure. ${ }^{31}$

Preparation of 1,5-diphenylcarbazone coated alumina. $1.5 \mathrm{~g}$ of alumina was added to $50 \mathrm{~mL}$ of a solution containing $100 \mathrm{mg}$ of sodium dodecyl sulfate (SDS). The solution was mixed with a magnetic stirrer. then $4 \mathrm{~mL}$ of $0.2 \%$ solution of 1.5-diphenylcarbazone was added and the $\mathrm{pH}$ was adjusted approximately to 7 . The solution was shaken for $15 \mathrm{~min}$. and was filtered through Millipore filter for preparation of the column (10 $\mathrm{mm}$ diameter and $18 \mathrm{~mm}$ height). A color change of alumina from white to reddishorange was used as the indication of immobilization of 1.5diphenylcarbazone on alumina. The coated alumina was used for preparation of the column. When kept in a refrigerator the sorbent is stable at least for one week

Determination of capacity of immobilized $\mathrm{H}_{2} \mathrm{DPC}$ on surfactant coated alumina. $50 \mathrm{~mL}$ of a solution containing $500 \mu \mathrm{g}$ of $\mathrm{Hg}$ (II) at optimum $\mathrm{pH}$ was added to $1.5 \mathrm{~g}$ of alumina coated with 1.5 diphenyl carbazone. The solution was mixed with magnetic stirrer for $l \mathrm{hr}$. the mixture was then centrifuged and the amount of mercury in supernatant solution was determined. The capacity of sorbent was determined by the difference of the amount of mercury in the original and final solution.

Recommended procedure. The $\mathrm{pH}$ of sample (500-2000 $\mathrm{mL}$ ) was adjusted to $\sim 7$ by addition of ammonia solution $\left(0.1 \mathrm{~mol} \mathrm{~L}{ }^{-1}\right)$. The samples were passed through the column of 1.5-diphenylcarbazone coated alumina with the aid of a suction pump. at a flow rate $20-60 \mathrm{~mL} \mathrm{~min}^{-1}$, to effect the deposition of analyte. The adsorbed mercury was then eluted with hydrobromic acid $\left(10 \mathrm{~mL} .1 \mathrm{~mol} \mathrm{~L}{ }^{-1}\right)$ with a flow rate of $1.5 \mathrm{~mL} \mathrm{~min}^{-1}$. The inorganic mercury in the eluent was directly measured by CVAAS. The total mercury was determined after the oxidation of metylmercury into the inorganic mercury with potassium permanganate. sulfuric/nitric acid solution according to the accepted procedure ${ }^{27-29}$ as follows: $2.5 \mathrm{~mL}$ of concentrate sulfuric acid $1.5 \mathrm{~mL}$ of concentrate nitric acid and $7.5 \mathrm{~mL}$ of $5 \%$ potassium permanganate solution were added to the eluent. After $15 \mathrm{~min}, 5 \mathrm{~mL}$ of $5 \%$ perosydisulfate was added and the solution was heated for 2 hrs at $90^{\circ} \mathrm{C}$ over a water bath. The solution was then let to cool and in order to reduce the extra permanganate. $3 \mathrm{~mL}$ of $6 \%$ hydroxyl ammonium chloride solution was added. The total mercury was then determined by CVAAS. The methyl mercury concentration was calculated by the difference between the values of the total mercury and mercury (II).

\section{Results and Discussion}

It was somewhat surprising to discover that 1.5-diphenylcarbazone. the classical analytical reagent. has not so far been incorporated in a resin matrix. This may be due to theoretical considerations. which suggest that 1.5-diphenylcarbazone should show little tendency to be coupled with species generally used to șinthesize chelating resins. However Hiradie et al $^{32}$ proposed that water-insoluble chelating sorbents could be trapped into the aggregate of sodium dodecyl sulfate (SDS) on alumina particles. The molecules of anionic surfactants can effectively be sorbed on the positively charged surface. Therefore the capability of $\alpha . \gamma$. fibrous alumina and sulfhydryl cotton on sorption of SDS was examined.

To $50 \mathrm{~mL}$ of water. $1.5 \mathrm{~g}$ of the base and $100 \mathrm{mg}$ of surfactant were added, and the $\mathrm{pH}$ was adjusted to different values with hydrochloric acid or aqueous ammonia solution. The suspension was shaken for $5 \mathrm{~min}$. and after centrifugation the amount of SDS left in solution was determined by toluidine blue method. ${ }^{1+4}$ The result of this study is shown in Figure 1 and clearly indicates the higher power of $\gamma$-alumina on sorption of SDS over a wide $\mathrm{pH}$ range (1-6) in compared

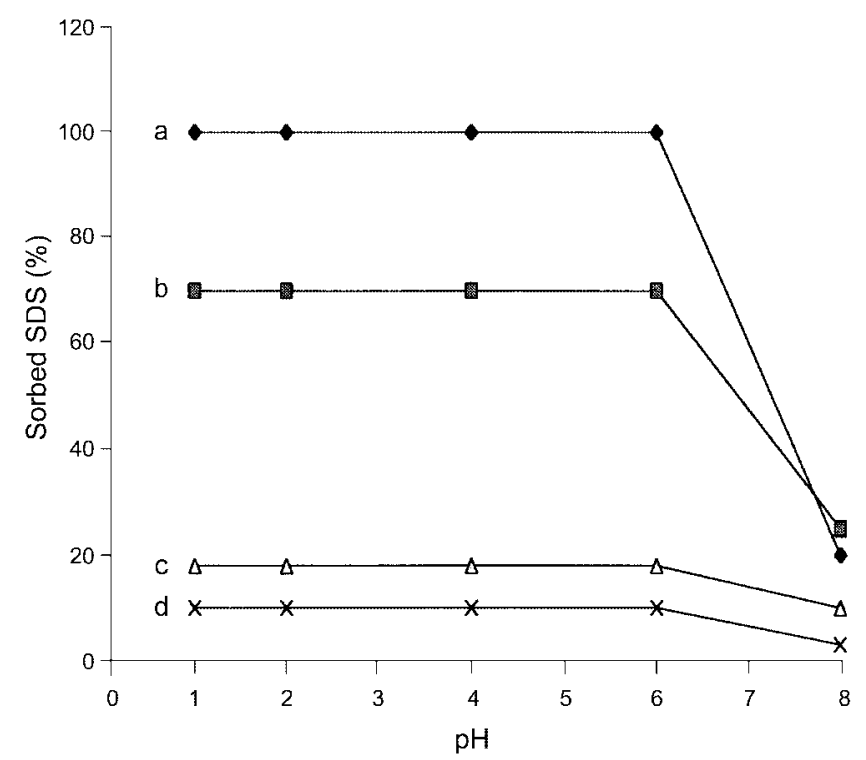

Figure 1. Effect of $\mathrm{pH}$ on absorption of SDS on different bases: a; * -alumina $\mathrm{b}$; sulfhydry l cotton $\mathrm{c} ;$-alumina $\mathrm{d}$; alumina fiber. 


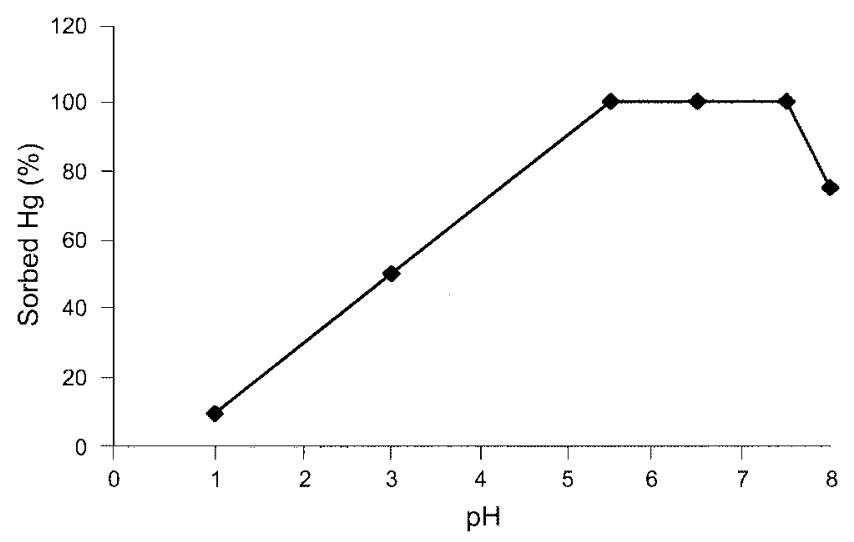

Figure 2. Effect of $\mathrm{pH}$ on mercury deposition: mercury concentration $10 \mathrm{ng} \mathrm{mL}^{-1}$ : concentrated volume $50 \mathrm{~mL}$ : flow rate $20 \mathrm{~mL}$ $\mathrm{min}^{-1}$.

with other bases used. The scant adsorption of SDS on $\alpha$ and fibrous alumina may be related to their chemically inert surface. while the lower capability of sulfhydryl cotton is probably due to the difference in structure and active groups ( $\mathrm{S}$ in sulfhydryl cotton and $\mathrm{O}$ in $\gamma$-alumina) of the two bases. Therefore the use of $\gamma$-alumina was found to be essential for the preparation of chelating sorbent. Mixing the $0.2 \%$ alcholic solution of 1.5 -diphenylcarbazone with the solution of SDS and alumina caused the 1.5-diphenylcarbazone to be trapped homogeneously on the hemi-micells or ad-micells formed by SDS on alumina surface and the color of alumina was changed from white to reddish-orange.

Analyte deposition was dependent on sample $\mathrm{pH}$ and as shown in Figure 2. high deposition efficiency was achieved over a $\mathrm{pH}$ range of 5.5-7.5. Mercury form a complex with 1.5-dipheny lcarbazone $\left(\mathrm{H}_{\searrow} \mathrm{DPC}\right)$ according to the following equation:

$$
\mathrm{H}_{2} \mathrm{DPC}+\mathrm{Hg}^{2-} \Leftrightarrow \mathrm{HgDPC}+2 \mathrm{H}^{+}
$$

Therefore. the progressive decrease in the retention of mercury at low $\mathrm{pH}$ is due to competition between the hydrogen ion and mercury for adsorption on DPC. While the decrease in adsorption at $\mathrm{pH}>7.5$ is probably due to factors such as the precipitation of mercury as mercury hydroxide and the formation of negative charge on the alumina surface. which

Table 1. Effect of flow rate on mercury deposition: mercury concentration $10 \mathrm{ng} 11 \mathrm{~L}^{-1}$ : concentrated volume $50 \mathrm{~mL}: \mathrm{pH}=7$

\begin{tabular}{cc}
\hline Flow rate $(\mathrm{mL} / \mathrm{min})$ & Adsorbed Mercury $(\%)$ \\
\hline 2 & $97 \pm 1$ \\
5 & $98 \pm 2$ \\
10 & $100 \pm 1$ \\
12 & $99 \pm 1$ \\
15 & $100 \pm 2$ \\
20 & $100 \pm 1$ \\
30 & $98 \pm 1$ \\
40 & $100 \pm 1$ \\
50 & $97 \pm 1$ \\
60 & $98 \pm 2$ \\
\hline
\end{tabular}

result in the reduction of SDS adsorption. To achieve high efficiency a $\mathrm{pH}$ of $\sim 7$ was selected for subsequent studies.

The results of Table $l$ indicate that the kinetic of exchange on the deposition step is very fast and signal response is independent on the flow rate up to $60 \mathrm{~mL} \mathrm{~min}{ }^{-1}$. which is one of the advantages of this method over the other solid phase extraction of mercury. ${ }^{13.14 .16 .24}$ In subsequent study a flow rate of $20 \mathrm{~mL} \mathrm{~min}{ }^{-1}$ was chosen as was more convenient. However. the kinetic of desorption of mercury from the colunn was slow: with $10 \mathrm{~mL}$ eluent the complete elution of analyte was possible at a flow rate of $1.5 \mathrm{~mL} \mathrm{~min}{ }^{-1}$.

The nature of eluents were found to have a significant effect on the desorption process of mercury from the column and its subsequent measurement by CVAAS. $10 \mathrm{~mL}$ of different eluents such as hydrochloric. hydrobromic. hydroiodic acids. acetone and thiourea were examined. and we found that lydrobromic acid was the most suitable eluent for this purpose. With $9 \mathrm{M}$ lydrochloric acid and $4 \mathrm{M}$ nitric acid the complete recovery of mercury was possible. but some of the SDS was also desorbed and caused foam formation during measurement. which blocked the $\mathrm{T}$ cell vapor generator. When $1 \mathrm{M}$ hydroiodic acid was used as eluent. a yellow precipitate. probably $\mathrm{HgI}_{2}$ was formed in the cold vapor generator. The mercury was completely recovered by acetone. but the background of the measurement was very noisy. The thiourea ( $\mathrm{pH}$ range $1-5$ ) as eluent was incapable of complete recovery of adsorbed mercury. Therefore. $\mathrm{HBr}$ was selected as the eluent and the effect of its concentration was considered. It was found that $10 \mathrm{~mL}$ of $1 \mathrm{M} \mathrm{HBr}$ solution is sufficient for quantitative recovery of adsorbed mercury:

The capacity of immobilized $\mathrm{H}_{2} \mathrm{DPC}$ on surfactant coated alumina was examined and was found to be $330 \mu \mathrm{g} \mathrm{g}^{-1}$ as $\mathrm{Hg}^{2-}$, which indicates that the column is suitable for preconcentration of traces of mercury.

Basic analytical performance. Performance characteristics of the technique were obtained by processing standard solutions of mercury: For a sample of $500 \mathrm{~mL}$ the calibration graph exhibited linearity over the range of $0.6-5 \mu \mathrm{g} \mathrm{L}^{-1}$. with a correlation coefficient of $0.9999(\mathrm{~A}=1.7724 \mathrm{C}+$ 0.1031 , where $\mathrm{A}$ is the area of peak and $\mathrm{C}$ is the concentration). The relative standard deviation $(n=8)$ at $1 \mu \mathrm{g} \mathrm{L}^{-1}$ (sample volume $500 \mathrm{~mL}$ ) was $1.7 \%$ and the detection limit. based on three times the standard deviation of the blank signal for processing $500 \mathrm{~mL}$ of solution, was $0.11 \mu \mathrm{g} \mathrm{L}^{-1}$. Extending the sample processing volume, however, results in improved method sensitivity. In the present study sampling volume up to $1000 \mathrm{~mL}$ for a solution of $2 \mu \mathrm{g} \mathrm{L}^{-1}$ mercury were investigated and response was found to increase linearly with volume $\left(r^{2}=0.9996\right)$.

The capability of the system to quantify the methylmercury at low level $\left(\mu \mathrm{g} \mathrm{L}^{-1}\right)$ was investigated. Consideration of the relative peak area of responses of $250 \mathrm{~mL}$ of standard solutions of methylmercury ( $2 \mu \mathrm{g} \mathrm{L}^{-1}$ with respect to mercury). mixture of mercury and methy lmercury $\left(2 \mu \mathrm{g} \mathrm{L}^{-1}\right.$ with respect to $\mathrm{Hg}$ ) after oxidation. and inorganic mercury $(2 \mu \mathrm{g}$ $\mathrm{L}^{-1}$ ) without oxidation revealed the suitability of the method 
Table 2. Effect of diverse anion on recovery of mercur: mercury

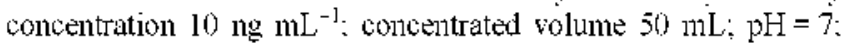
flow rate $20 \mathrm{~mL} \mathrm{minin}^{-1}$

\begin{tabular}{ccc}
\hline Anions & mole ratio of $\mathrm{X}^{\mathrm{n}-} / \mathrm{Hg}^{\hat{*}^{-}}$ & Recovery (\%) \\
\hline $\mathrm{ClO}_{4}^{-}$ & 1000 & 99.4 \\
$\mathrm{Cl}^{-}$ & 1000 & 99.5 \\
$\mathrm{NO}_{3}{ }^{-}$ & 1000 & 96.5 \\
$\mathrm{SO}_{4}^{2-}$ & 1000 & 97.8 \\
$\mathrm{CH}_{3} \mathrm{COO}^{-}$ & 650 & 97.6 \\
$\mathrm{C}_{2} \mathrm{O}_{4}{ }^{--}$ & 500 & 98.5 \\
$\mathrm{I}^{-}$ & 500 & 99.7 \\
$\mathrm{CO}_{2}{ }^{--}$ & 500 & 98.5 \\
$\mathrm{Br}^{-}$ & 500 & 99.8 \\
\hline
\end{tabular}

Table 3. Effect of divers cation on recovery of mercury: mercury concentration $10 \mathrm{ng} \mathrm{mL}$; concentrated volume $50 \mathrm{~mL} ; \mathrm{pH}=7$; flow rate $20 \mathrm{~mL} \mathrm{minn} \mathrm{m}^{-1}$

\begin{tabular}{ccc}
\hline Cation & mole ratio of $\mathrm{M}^{\mathrm{n}+} / \mathrm{Hg}^{2+}$ & Recovery $(\%)$ \\
\hline $\mathrm{Ca}^{2+}$ & 100000 & 99.2 \\
$\mathrm{Mg}^{\hat{2}^{-}}$ & 16400 & 99.3 \\
$\mathrm{Na}^{-}$ & 2000 & 99.8 \\
$\mathrm{~K}^{-}$ & 1030 & 99.7 \\
$\mathrm{Ag}^{+}$ & 185 & 98.7 \\
$\mathrm{Cd}^{\hat{y}^{-}}$ & 180 & 98.6 \\
$\mathrm{~Pb}^{{ }^{+}}$ & 100 & 98.5 \\
$\mathrm{Ni}^{2-}$ & 18 & 98.5 \\
$\mathrm{Cu}^{-}$ & 17 & 99.7 \\
$\mathrm{Zn}^{2+}$ & 16 & 98.6 \\
\hline
\end{tabular}

for quantitative measurement of methylmercury.

Effect of diverse ions. The selectivity and utility of the method were examined in the presence of various ions (Table 2 and 3 ). An error of $\pm 3 \%$ in recovery was considered tolerable.

As the results indicated the cations and anions at the given mole ratio in the table. were tolerated. This suggest a preferential uptake of mercury relative to matrix ions. and it is projected that in the analysis of samples. the deposition efficiency would not be affected by the presence of a high concentration of matrix ions.

Application. The feasibility of the technique for the determination of mercury in different matrices was examined. Recovery of mercury (II) and methy'mercury from a synthetic water sample having the composition $\left(\mathrm{mg} \mathrm{L}^{-1}\right) \mathrm{Na}^{+} 30 . \mathrm{K}^{-} 8$. $\mathrm{Mg}^{2+} 40 . \mathrm{Ca}^{2+} 110 . \mathrm{Cl}^{-} 248 . \mathrm{SO}_{4}{ }^{2-} 158$, and conforming to acceptable limits for drinking water was studied. The results (Table 4) show that the presence of salts do not affect the degree of sorption of these cations.

The procedure was also applied to the determination of inorganic and total mercury in well water. spring water and seawater. Reliability was checked by spiking experiments. The results of this investigation are given in Table 5 and 6 . It can be seen that the recovery of spiked samples is good. which indicates the capability of the sy'stem in determination of mercury for water samples.
Table 4. Recovery of mercury and methylmercury cations from synthetic water:: concentrated volume $500 \mathrm{~mL}: \mathrm{pH}=7$ : flow rate $20 \mathrm{~mL} \mathrm{~min}^{-1}$

\begin{tabular}{ccccc}
\hline Species & $\begin{array}{c}\text { Added } \\
(\mathrm{ng})\end{array}$ & Detennined* & $\begin{array}{c}\text { Recovery } \\
(\%)\end{array}$ & RSD (\%) \\
\hline $\mathrm{Hg}^{2-}$ & 300 & $301.8 \pm 8.2$ & 100.6 & 2.7 \\
& 500 & $499.6 \pm 7.1$ & 99.9 & 1.4 \\
$\mathrm{CH}_{3} \mathrm{Hg}^{-}$ & 300 & $302.5 \pm 4.5$ & 100.8 & 1.5 \\
& 500 & $494.7 \pm 12.6$ & 98.9 & 2.5 \\
\hline
\end{tabular}

*Mean \pm standard divination $(n=3)$.

Table 5. Determine of inorganic mercury in natural water: concentrated volume $500 \mathrm{~mL} ; \mathrm{pH}=7$; flow rate $20 \mathrm{~mL} \mathrm{~min} \mathrm{~m}^{-1}$

\begin{tabular}{|c|c|c|c|c|}
\hline & \multicolumn{2}{|c|}{ Mercury (ng L L $\left.{ }^{-1}\right)$} & \multirow{2}{*}{$\begin{array}{c}\text { Recovery } \\
(\%)\end{array}$} & \multirow{2}{*}{$\begin{array}{l}\text { RSD } \\
(\%)\end{array}$} \\
\hline & Added & Detenmined* & & \\
\hline \multirow[t]{2}{*}{ Well water } & 0 & $138.5 \pm 4.3$ & & 3.1 \\
\hline & 300 & $444.4 \pm 5.6$ & 101.3 & 1.3 \\
\hline \multirow[t]{2}{*}{ Spring water } & 0 & not detected & & \\
\hline & 300 & $301.5 \pm 7.5$ & 100.5 & 2.5 \\
\hline \multirow[t]{2}{*}{ Sea water } & 0 & $125.3 \pm 2.8$ & & 2.2 \\
\hline & 300 & $428.4 \pm 4.3$ & 100.7 & 1 \\
\hline
\end{tabular}

* Mean \pm standard dirination $(n=3)$

Table 6. Determine of total mercury in natural water: concentrated volume $500 \mathrm{~mL}: \mathrm{pH}=7$ : flow rate $20 \mathrm{~mL} \mathrm{~min}^{-1}$

\begin{tabular}{ccccc}
\hline & \multicolumn{2}{c}{ Mercury $\left(\right.$ ng $\left.\mathrm{L}^{-1}\right)$} & $\begin{array}{c}\text { Recovery } \\
(\%)\end{array}$ & $\begin{array}{c}\text { RSD } \\
(\%)\end{array}$ \\
\cline { 2 - 3 } added & Determined & & \\
\hline Well water & 0 & $140.4 \pm 4.3$ & & 3.1 \\
Spring water & 300 & $437.8 \pm 4.3$ & 99.4 & 1 \\
& 0 & not detected & & \\
Sea water & 0 & $299.4 \pm 3.8$ & 99.8 & 1.3 \\
& 300 & $131.9 \pm 4.3$ & & 3.3 \\
\end{tabular}

*Mean \pm standard dirination $(n=3)$.

\section{Conclusion}

It has been demonstrated that the $\mathrm{H}_{2} \mathrm{DPC}$ immobilized on surfactant coated alumina provides a novel. fast route for determination of inorganic and total mercury in several categories of natural waters. The main benefits of solid phase extraction methodology. were enhanced sensitivity: attainability of large preconcentration factor and facility of separation.

Future work will be directed at biological samples and assessment of the multielement enrichment capability of column for determination of ultratrace mercury in seawater.

Acknowledgment. The authors wish to thank the graduate school of Yazd university for its support.

\section{References}

1. DItri, P. A.: D|Itri. M. Mercury Contamination: A Human Tragedu: John Wiley and Sons. Inc.: New York. 1977. 
2. Baird C. Enwromental Chenistry: W. H. Freeman and Company: 1999. pp 386-395.

3. Lee. K. S.: Choi. H. S.: Kim. S. T.: Kim. Y. S. J. Korean Chem. Soc. 1991. 35.4

4. Tanaka, H.: Morita, H.: Shimomura. S; Okannato. K. Andl. Sci. $1993,8,2$.

5. Riddiford. A. C. Adhance in Electrochmistry and Electrochmical Engineening: 1966: p 4 .

6. Gritzner. G.: Kata. J. Electrochim. Acta 1984. 29.869.

7. Zaporozhets. O.: Petrunick. N.: Sukhan. V. Talamfa 1999. 50. 865.

8. Ma. W. X: Liu, F.: Li, K. A.; Chen. W: Tong. S. Y. Anal Chim. Acta 2000. $416,191$.

9. Hafez. M. A. H.: Kenawy. I. M. M.: Akl. M. A.: Lashein. R. R. Talanta 2001, 53.760.

10. Pierce. T. B. Anal Chim 1961. 24. 146.

11. Grote. M.: Kettrup. A. Anal. Chim. Acta 1985. 172. 223.

12. Howard A. G.: Arbab-Zavar. M. H. Talonta 1979, 26, 895.

13. Ide, S. Kitakvishn Kogvo Koto Senmon Gakko Kenki Hokoka. 12. 127: as citted Chem. Atst 1984. 101. 116442d.

14. Manzoori. J. L.: Sorouraddin. M. H.: Haji Shabani. A. M. J. Anal. At. Spectrom. 1998, 13.305.

15. Sjncheza. D. M:: Martin. F.: Morante. R.: Marin. J.: Munuera. M. L. Tatanta 2000, 52,671 .

16. Mahmoud M. E: Osmana, M. M.: Amerb, M. E. Anal. Chim. Acta 2000. 415,33 .
17. Tanak, H.: Ghikama M: Haradu. A.: Ueda, T:; Yube. S. Talanta 1976. 23,489

18. Emteborg. H.: Baster. D. C.: Sharp. M.: Frech. W. Analyst 1995. 120.69 .

19. Huabin. F.: Xiang. R. I. Anal. Tox 2000. 24. 704.

20. Baba. Y: Matsumra, N.: Shiomori. K.: Kawano. Y. Anal. Sci 1998. $1+687$.

21. Wang, H. C. Hwang, Y. C.: Hsith, C. J.; Kuo. M. S. Anol, Sci 1998. 14.983

22. Malunood. M. E. Anal. Chim Acta 1999. 398. 297.

23. Blanco. R. M.: Villaneva. M. T.: Sjnchez. J. E.: Medela. A. S. Anal Chm . Acta $2000,+19,137$.

24. Mahmood, M. E: Gohar, G. A. Talana 2000. 51. 77.

25. Balt. S.: Vandalen. G. Anal. Chim Acta 1962. 27,188.

26. Hiraide. M.: Hori. J. Anal Sci. 1999. 15. 1055.

27. Koop. T. F.: Longbottom. M. C.: Lobring. L. B. Cold rapor for Detruining 1 fercury 1972. 64. 20.

28. Annual Book of ASTM Standards, Part 31. Water Standard 1976. [13223-73. 343

29. Standard Methods for the Examtination of Water and Wastewater. $14^{\text {th }}$ ed: $1975:$ p 156.

30. Dadfarnia. S.: Green. I.: Mclood. C. W. Anal Procc. 1994. 31.61.

31. Lee, T. H.: Mowrer J. Anal. Chim. Acta 1988, 221. 259.

32. Hiraide, M.; Sorouraddin. M. H; Kawaguchi, H. Anal. Sci. 1994. 10. 125 . 